\title{
IMPACT OF TYPE OF PITFALL TRAPS AND PRESERVING AGENT ON ENTRAPPED REPRESENTATIVES OF THE CARABIDAE (COLEOPTERA)
}

\author{
J. Šafář, P. Štastná, V. Hula
}

Received: December 16, 2009

\begin{abstract}
ŠAFÁŘ, J., ŠŤASTNÁP., HULA, V.: Impact of type of pitfalltraps and preserving agenton entrapped representatives of the Carabidae (Coleoptera). Acta univ. agric. et silvic. Mendel. Brun., 2010, LVIII, No. 2, pp. 213-218

This paper focuses on the type of cover and preserving agent influence on composition of entrapped fauna of Carabidae beetles. The research took place in the northern part of the protected landscape area of Ždárské vrchy, south from Kameničky municipality in rural district of Chrudim. Epigeic fauna was monitored one month from April $30^{\text {th }}$ to June $5^{\text {th }} 2008$ - in the period of the highest activity of most Carabidae species. Traps were located in Latin square with five meter distance, using three preserving agents (formaldehyde, ethylene glycol, sodium chloride solution) and three types of covers above pitfall traps (acrylic glass cover, no cover, or wooden board put above the trap). Within the research 1123 Carabidae specimens belonging to 21 species were entrapped. The most numerous was Poecilus cupreus (915 specimens) in which also the strongest relationship to formaldehyde was detected. The redundancy analysis (RDA) from CANOCO package was used for statistical evaluation. With monitored variables, a significant influence $(T=0.137, \mathrm{~F}=3.020, \mathrm{P}=0.0240)$ of formaldehyde on presence of some Carabidae species was confirmed (Poecilus cupreus, Amara lunicollis, Pterostichus diligens, and Bembidion guttula). Influence of the cover above the pitfall trap on species range in the trap was not confirmed $(\mathrm{T}=0.062, \mathrm{~F}=2.574, \mathrm{P}=0.0710)$.
\end{abstract}

Carabidae, pitfall trap, formaldehyde, ethylene glycol, sodium chloride, RDA

Ground traps belong among the most common methods for invertebrates trapping and they are used for various studies. Multiple types of traps and various preserving agents as well as various types of covers over the traps are widely used. Additionally, pitfall traps are appointed for the main trapping method for biomonitoring (Absolon et al., 1994). Unfortunately, the fact that various traps and agents can influence entrapped epigaeic fauna is not taken into consideration. The preserving agent used in pitfall traps can have attractive, neutral, or sometimes repellent effect, variable across taxonomic groups of animals and individual species. The most commonly used agents are ethylene glycol, formaldehyde, and sodium chloride solution. Ethylene glycol attractiveness to arthropoda was reported by Holland (2002), Adis (1976, 1979), and Heydmann (1956). Attractiveness of formaldehyde to arthropoda is supported by Briggs (1961), Petruška (1967), Adis (1976, 1979), Heydmann (1956), and Skuhravý (1957, 1970). Alcohol and water are believed to be repellent (Adis, 1979; Briggs, 1961). Reaction to the preserving agent also depends on sex. The numbers of male and female specimens entrapped in pitfall traps are different due to sexual pheromones (aldehyde group). Not least, the number of female and male specimens varies according to the season, because then number might depend on pheromone production (Adis, 1974). Following ANCLP CR protocol (Chobot et al., 2005), sodium chloride should be used as preserving agent in protected areas. Ethylene glycol as well as formaldehyde should only be avoided because they are considered to be misrepresenting. Used covers vary as well, e.g. the above mentioned protocol recommends traps with acrylic glass covers, which are described as very improper by, e.g., 
Adis (1979). However, many other authors do not respect findings by Adis (1979) while his publication about various pitfall traps is considered to be fundamental (see Web of Science database). In majority of papers it is declared that pitfall traps were covered by a cover but they do not state of what material were these covers (e.g. Štastná, Bezděk, 2001; Kula, Purchart, 2004). Thiele (1977) then mentions that attractive influence on some Carabidae species can have negative influence on other non-attracted species since they are pushed out by direct competition and they cannot get into the trap.

\section{MATERIAL AND METHODS}

\section{Monitored area description}

Material was collected in experimental area Vojtěchův kopec $673 \mathrm{~m}$ a. s. l. (GPS localization: 49 43'31.24" N, 1558'44.68' E)which has been protected as a nature reserve since 1990 lies close to the monitored locality. The locality is situated near Kameničky municipality (rural district of Chrudim, protected landscape area of Žd'árské vrchy) in the level of $650 \mathrm{~m}$ a. s. l. Traps were located in homogeneous vegetation of waterlogging lawns of submontane type dominated by Nardus stricta. Further common plants were: Nardus stricta, Ranunculus repens, Ranunculus acre, Peucedanum palustre, Viola palustris, Taraxacum sp., Geum rivale, Deschampsia cespitosa, Hypericum sp., and Bistrota major.

\section{Description of experiment design}

Pitfall traps of uniform size (plastic glasses $0,5 \mathrm{l}$ ) differed in preserving agents ( 3 options) and types of covers ( 3 options). We used $4 \%$ aqueous solution of formaldehyde, $5 \%$ aqueous solution of ethylene glycol, and saturated solution of sodium chloride (kitchen salt) were used. The covers were either of sololite (non-translucent material) or they were wooden boards loosely laid down above the trap at the vegetation or the trap had no cover. The traps were arranged so that in one row there were all nine modifications, and there were nine rows all together - so called Latin square (Fig. 2). Distances between the traps were $5 \mathrm{~m}$. This arrangement created repetition of trap modifications always in diagonal direction in the square in total number of 81 pcs taking up area of $1,600 \mathrm{~m}^{2}$. The traps were placed in the locality for one month from April $30^{\text {th }}$ to June $5^{\text {th }}$ 2008, which is a period of the highest sexual activity of most Carabidae species (Thiele, 1977). Carabidae specimens were determined by keyes of Hůrka (1996).

Visualization and statistical processing of the data were performed utilizing package of Canocco for Windows - ver. 4.54 (Ter Braak \& Šmilauer, 1998). PCA analysis was done because we detected the length of gradient ( $>3)$, and redundancy data analysis (RDA) was used for the final processing.

\section{RESULTS AND DISCUSSION}

In total 21 species and 1123 specimens of Carabidae were entrapped in the monitored locality. All entrapped species is listed in Tab. I. The most abundant species were Poecilus cupreus (915 specimens) and Carabus granulatus (99 specimens). From the point of multitude of entrapped specimens, the traps were very diverse.

Species reaction to preserving agent using various types of covers over the trap is clear from the Fig. 1. Formaldehyde as preserving agent with a cover over the trap attracts most species. In case of so called full model (all variables tested together - Tab. II), it was detected that the following species incline to formaldehyde: Poecilus cupreus, Amara lunicollis, Pterostichus diligens, Pterostichus nigrita, and Bembidion guttula and other agents are not attractive for any of the detected species. In a test, where only preserving agents were considered and cover variables were filtered off, it was clear that formaldehyde was attractive for the following species listed according their abundance: Poecilus cupreus (915 specimens), Amara lunicollis (22 specimens), Pterostichus diligens (13 specimens), and Bembidion guttula (11 specimens). Evaluation of cover influence did not show significant results (see Tab. II) and thus it can be declared that they do not have any influence on the range and number of entrapped carabids.

I: Numbers of entrapped specimens according to individual species

\begin{tabular}{|c|c|}
\hline Species & $\begin{array}{l}\text { Number of } \\
\text { specimens }\end{array}$ \\
\hline $\begin{array}{l}\text { Abax parallelepipedus (Miller et } \\
\text { Mitterpacher, 1783) }\end{array}$ & 15 \\
\hline Agonum sexpuntatum (Linnaleus, 1758) & 1 \\
\hline Amara communis (Panzer, 1797) & 7 \\
\hline Amara lunicollis (Schiodte, 1837) & 22 \\
\hline Amara ovata (Fabricius, 1792) & 1 \\
\hline Anisodactylus binotatus (Fabricius, 1787) & 2 \\
\hline Bembidion guttula (Fabricius, 1792) & 11 \\
\hline Carabus cancelatus (Illiger, 1798) & 5 \\
\hline Carabus glabratus (Paykull, 1797) & 5 \\
\hline Carabus granulatus (Linnaeus, 1758) & 99 \\
\hline Clivina collaris (Herbst, 1784) & 1 \\
\hline Clivina fossor (Linnaeus, 1758) & 1 \\
\hline Dyschirius globosus (Herbst, 1794) & 2 \\
\hline Harpalus latus (Linnaeus, 1758) & 1 \\
\hline Oodes helopioides (Fabricius, 1792) & 3 \\
\hline Poecilus cupreus (Linnaleus, 1758) & 915 \\
\hline Poecilus versicolor(Sturm, 1824) & 4 \\
\hline Pterostichus diligens (Sturm, 1824) & 13 \\
\hline Pseudoophonus griseus (Panzer, 1797) & 1 \\
\hline Pterostichus nigrita (Paykull, 1790) & 8 \\
\hline Pterostichus vernalis (Panzer, 1796) & 6 \\
\hline Number of specimens & 1123 \\
\hline Number of species & 21 \\
\hline
\end{tabular}


II: Test of significance of all models (RDA - Canoco)

\begin{tabular}{lccc}
\hline \multicolumn{1}{c}{ TEST } & T & F & $\begin{array}{c}\text { Signifikance } \\
(\mathbf{P})\end{array}$ \\
\hline Preserving agent and cover & 0.137 & 3.020 & $* *$ \\
Preserving agent & 0.075 & 3.173 & $*$ \\
Cover & 0.062 & 2.574 & NS \\
\hline
\end{tabular}

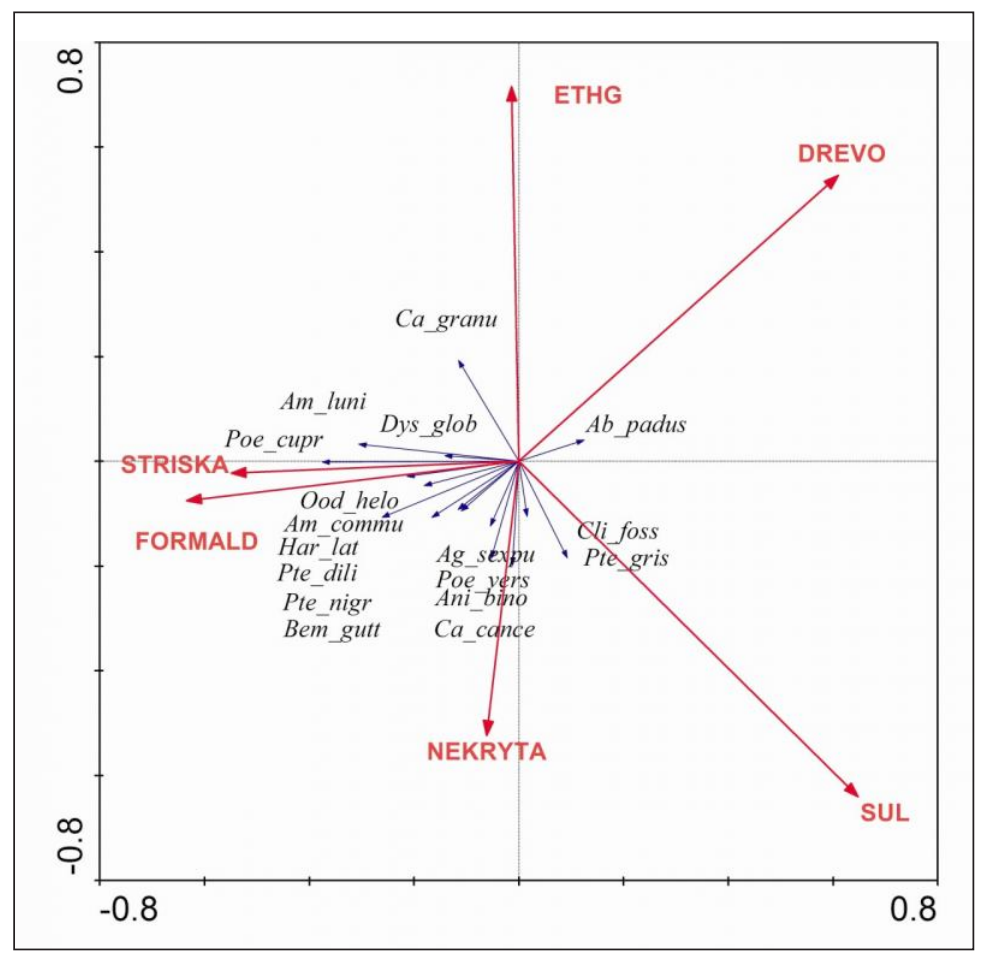

Legend:media - ETHG (ethylene glycol), SUL (sodium chloride), FORMALD (formaldehyde); cover - DREVO (wooden board), NEKRYTA (no cover), STRISKA (acrylic glass cover)

1: Result of RDA analysis of Carabidae beetles fauna reaction to preserving agent as well as types of covers

Several authors refer that formaldehyde, which is attractive for more representatives, is not a natural substance, and thus it is surprising that this item can have so attractive influence on epigeon carabids. However aldehydes, among which formaldehyde belongs, are substances commonly used by invertebrates for communication (in particular sexual pheromones - Thiele, 1977; Adis, 1979), and so they probably perceive formaldehyde incorrectly. Adis (1979) states that there is a significant influence of the cover on entrapped fauna, which is clearly displaced by our study (highly probative, see Tab. II) and we suppose that types of covers which are used do not matter at least in habitats, such as waterlogged grass fields. A question is whether influence of the cover does not differ depending on the monitored habitat, for example microclimate influence can be very significant in xerothermic places (local desiccation and traps as sources of local moisture). Microclimate influence, in particular with metal covers, was discussed by Heydemann (1953).
While drawing up any experiments using diverse types of traps, not only pitfall traps, it is necessary to take into account preserving liquid impact, which we, as well as many other authors, have confirmed. It is essential to take into account, at comparing results of individual works, that various species of Carabidae can be in traps with different preserving agents and that works with different preserving agents are basically incomparable. From the biomonitoring or other work protocols point of view, it is essential to unite these actions and it is not possible to implicitly accept rebukes of individual experts concerning suitability of diverse agents for following processing. In spite of negative features (toxicity, carcinogenicity), formaldehyde is clearly the best agent for preservation of specimens and by unified usage of it only an error of the first kind would occur (Lepš, 1996), which is not an error in case of unified usage. If diverse agents enter into protocol instructions for pitfall traps, errors of second kind appear, and thus the studies are absolutely incomparable. 


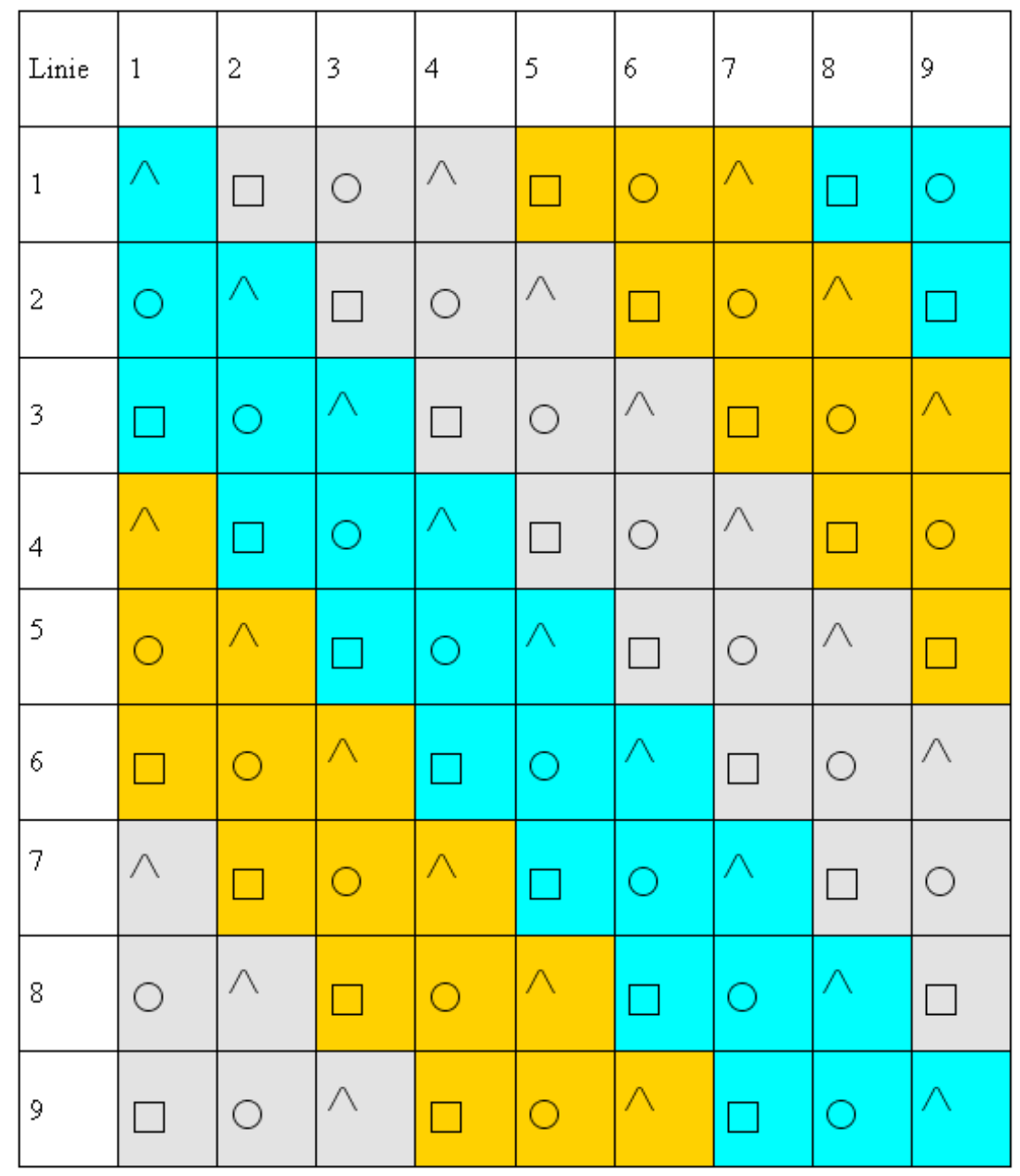

Legend: Symbol: (^) trap with a cover, ( $\odot$ ) trap with no cover, ( $\square)$ trap with a board, color: blue - ethylene glycol, yellow - formaldehyde, gray - sodium chloride

2: Latin square

\section{SOUHRN}

Vliv typu zemní pasti a konzervační látky na odchyt druhů čeledi Carabidae (Coleoptera) Práce hodnotí rozdíly v odchytech střevlíkovitých (Carabidae) do zemních pastí při použití nejužívanějších metodik sběru půdní fauny, resp. vlivem použité konzervační látky a zastřešení zemní pasti. Výzkum byl prováděn v severní ćásti chráněné krajinné oblasti Ždárské vrchy, jižně od obce Kameničky v okrese Chrudim. Odchyt epigeické fauny probíhal měsíc, 30. 4.-5. 6. 2008, tedy v období největší aktivity střevlíkovitých brouků (Carabidae). Pro vyhodnocení byla použita RDA analýza. Na pokusné ploše jsme použili celkem 81 pastí, které byly umístěny v designu tzv. latinského čtverce. Tento design byl zvolen proto, abychom předešli možnému působení okolních pastí na odchycený materiál v každé jednotlivé pasti a nedošlo ke zkreslení dat.Z hlediska běžně užívaných metod je nejčastěji užívanou pastí formaldehydová zemní past krytá stř̌šsou, ale pro potř̌eby ochrany př̌írody či faunistické práce je často využíváno ethylenglykolu či roztoku kuchyňské soli, jako konzervačního média. Práce studující problematiku zemních pastí běžně nezohledňují odchylky, které při odchytu do zemních pastí nastanou použitím jediného typu pasti a konzervačního média. Současně je jen velmi málo známo o ekologii jednotlivých druhů epigeonu, nejen střevlíků. Většinou nejsou respektována základní zjištění nejvýznamnějššch prací v oboru a dochází ke špatné interpretaci dat. Chyby vznikající při výzkumech jsou přehlíženy nebo se spíše s těmito odchylkami ani autoři nesetkají, protože při užití jednoho typu pastí se specifickým konzervačním médiem nejsou viditelné rozdíly ve výsledcích. Pokud však dojde k porovnání na základě literatury, již není často možné zjistit, který typ stř̌ššky či který typ konzervačního média byl použit. 
Při naší studii bylo odchyceno 1123 kusů střevlíků, kteří náleželi 21 druhům (Tab. I.). Nejpočetnějšími druhy byly Poecilus cupreus v počtu 915 ks a Carabus granulatus v počtu 99 ks. Co se týče preference konzervačního média a stř́šky, tak v tzv. full modelu $(\mathrm{T}=0,137, \mathrm{~F}=3,020, \mathrm{P}=0,0240)$ byla prokázána signifikantní vazba několika druhů střevlíků na formaldehyd (Poecilus cupreus, Amara lunicollis, Pterostichus diligens a Bembidion guttula) a na ethylenglycol Carabus granulatus. Vliv samotného média byl signikantní ( $\mathrm{T}=0,075, \mathrm{~F}=3,137, \mathrm{P}=0,0710)$, ale vliv samotné stř́šky již ne ( $\mathrm{T}=0,062, \mathrm{~F}=2,574, \mathrm{P}=0,0710)$. Pro výzkum epigeické fauny vyplývá, že je potřeba zvolit vhodné konzervační médium a minimálně na lokalitách podobných naší nezáleží na použitém zakrytí zemní pasti. Pro případnou možnost porovnání publikovaných údajů (např. pro makroekologické studie) je nutné vždy v práci uvádět konzervační médium a použité zastřešení zemní pasti.

Carabidae, zemní past, formaldehyd, etylenglykol, solný roztok, RDA

\section{Acknowledgment}

This study was supported by the Research project VaV-MZP-CR-SP/2D4/59/07. Authors would like to thank to Luboš Purchart for identification of some specimens and to Zuzana Vítková, Hana Šefrová, and Jan Bezděk for their help with collecting and processing the material. We would like to thank to Zdeněk Laštůvka especially for his valuable comments to the manuscript.

\section{REFERENCES}

ABSOLON, K., BENDA, P., CHRUDINA, Z., KLAUDISOVÁ, A., MARTIŠKO, J., PAŘIL, P., ŘIČÁNEK, M., 1994: Metodika sběru dat pro biomonitoring v chráněných územích. ČSOP, Praha, 70 pp.

ADIS, J., 1974: Bodenfallenflänge in einem Buchenwald und ihr Aussagewert. Diplomarbeit, Göttingen, 94 pp.

ADIS, J., 1976: Bodenfallenfänge in einem Buchenwald und ihr Aussagewert. Ökologie - Arbeiten, Berichte, Mitt. (Sollingprojekt - Zool. Beitr.), Ulm, 49 pp.

ADIS, J., 1979: Problems of interpreting arthropod sampling with pitfall traps. Zool. Anz. (Jena), 202: 177-184.

BARBER, H. S., 1931: Traps for cave-inhabiting insects. J. Elisha Mitchell sci. Soc., 46: 259-266.

BRIGGS, J. B., 1961: A comparison of pitfall trapping and soil sampling in assessing populations of two species of ground beetles (Coleoptera: Carabidae). Rep. E. Malling Res. Station 1960: 108-112.

CHOBOT, K., ŘEZÁČ, M. \& BOHÁČ, J., 2005: Epigeické skupiny bezobratlých a jejich indikační schopnosti. s. 239-248. In: Vačkář: Ukazatelé změn biodiverzity. Academia, Praha, 298 pp.

HOLLAND, M. J., 2002: The Agroecology of Carabid Beetles. Intercept Limited, Hampshire, 356 pp.

HEYDEMANN, B., 1953: Agrarökologische Problematik, dargetan an Untersuchungen über die Tierwelt der Bodenoberfläche der Kulturfelder. Ph.D. Thesis. University of Kiel, Germany, 433 pp.
HEYDEMANN, B., 1956: Über die Bedeutung der „Formalinfallen“ für die zoologische Landesforschung. Faun. Mitt. Norddtschl., 6: 19-24.

HU゚RKA, K., 1996: Carabidae of the Czech and Slovak Republics. Kabourek, Zlín, 565 pp.

KULA, E., PURCHART, L., 2004: The ground beetles (Coleoptera: Carabidae) of forest altitudinal zones of the eastern part of the Krušné hory Mts. J. of For. Sc., 50(10): 456-463.

LEPŠ, J., 1996: Biostatistika. Jihočeská univerzita, České Budějovice, 166 pp.

PETRUŠKA, F., 1967: Stř̌evlíkovití jako součást entomofauny řepných polí Uničovnské roviny (Coleoptera, Carabidae). Acta Univ. Pal. Olomouc. 25: 12l-243.

SKUHRAVÝ, V., 1957: Metoda zemních pastí. Čas. Českoslov. Společ. ent. 54: 27-40.

SKUHRAVÝ, V., 1970:Zur Anlockungsfähigkeit von Formalin für Carabiden in Bodenfallen. Beiter. Ent. 20: 374-381.

ŠŤASTNÁ, P., BEZDĚK, J., 2001: Tentative results of Carabidae (Coleoptera) investigation in two plots of the Research Center Vatín. Acta. Univ. Agric. et Silvic. Mendel. Brun. 46(3): 101-104

TER BRAAK, C. J. F., ŠMILAUER, P., 1998: CANOCO Reference Manual and User's Guide to Canoco for Windows: Software for Canonical Community Ordination (version 4), Ithaca, USA, Microcomputer Power, 352 pp.

THIELE, H. U., 1977: Carabid Beetles in Their Environments. Springer - Verlag Berlin, Heidelberg, 354 pp. 
